\title{
Histomorphic and Histochemical Observations on the Adrenals of the Reserpine-treated Lizards, Calotes versicolor
}

\author{
S.K. Baneriee and (Miss) Amiya Ghosh \\ Institute of Science Education, Rajbati, Burdwan, \\ West Bengal, India
}

Received April 23, 1974

Treatment with reserpine leads to an initial depletion of adrenomedullary catecholamines, although the long-term action of this drug is a marked inhibition of adrenal medullary secretion (Carlsson and Hillarp 1956, Burger 1957, Hertting et al. 1961). So far as its effect on the adrenocortical activity is concerned, it is on record that although reserpine itself increases adrenocortical secretion, reserpineinduced inhibition of such secretion may occur if adrenocortical hormone levels are high before the drug is applied (see Ganong and Lorenzen 1967). The effect of reserpine on the adrenal activity has been intensively studied on various mammalian species (Carlson and Hillarp 1956, Burger 1957, Camanni et al. 1958, Eränkö and Hopsu 1958, Hertting et al. 1961, Maickel et al. 1961, Eechaute et al. 1962, Viveros et al. 1969) and birds (Ghosh and Ghosh 1963, Ghosh and Datta 1969). Comparatively, very little investigation has so far been carried out in this respect on the lower vertebrate groups (Olivereau 1963, Banerji 1970). The present investigation deals with histomorphic and histochemical observations on the cortical and medullary activities of the adrenals of a reptile following treatment with a single high dose of reserpine.

\section{Material and methods}

Adult garden lizards, Calotes versicolor (Daudin) of both sexes, acclimatized to laboratory conditions for 3 days were used. Acclimation and feeding of the lizards were done in the manner as described earlier (Ghosh et al. 1973). On the fourth day 30 lizards were given a single intramuscular injection of reserpine (Serpasil: Ciba) at the individual dose of $0.8 \mathrm{mg} / 100 \mathrm{gm}$ body weight. 25 lizards were maintained as controls. At least 5 lizards from the controls as well as treated groups were sacrificed by quick decapitation after a lapse of 4, 24, 72 and $120 \mathrm{hr}$ respectively. Pieces of the quickly dissected out adrenals of each individual were suitably fixed for the histomorphic and histochemical studies.

For histomorphic studies tissues were fixed for $24 \mathrm{hr}$ in aqueous Bouin's and following the routine procedures $6 \mu$ thick paraffin cross sections were made. Sections were stained with haematoxylin and eosin. For karyometric study the nuclear volumes of the cortical and medullary cells were calculated according to the method of Palkovits as described by Srebro (1970). For this purpose, the long and short dimensions of 50 nuclei from cortex and 50 from the medulla in each individual 
were taken and the nuclear volumes were calculated according to the formula $\mathrm{v}=(\pi / 6) \mathrm{LB}^{2}$.

For histochemical studies, the localizations of ascorbic acid and catechol hormones in the adrenal medulla were performed. The method as described by Zarrow et al. (1964) was followed for localization of ascorbic acid. Tissue pieces were placed in fixing tubes (thoroughly covered with black papers to prevent entry of light) containing freshly prepared $5 \%$ silver nitrate solution ( $\mathrm{pH}$ adjusted to 2 to 2.5 by adding drops of acetic acid) and incubated at $55^{\circ} \mathrm{C}$ for $1 \mathrm{hr}$. Subsequently, the tissues were first washed with distilled water for 20 minutes and then with $5 \%$ sodium thiosulphate solution for 45 minutes. The routine procedures were followed for dehydration, clearing and paraffin sectioning. $15 \mu$ thick cross sections were deparaffinized in xylol and mounted in canada balsam. The method of Hillarp and Hökfelt (1955) was followed for the localizations of medullary catechol hormones. Tissue pieces were placed for 24 hours in a mixture of ten volumes of $5 \%$ potassium dichromate and one volume of $1 \%$ potassium chromate solutions for both adrenaline and noradrenaline, and in a saturated solution of potassium iodate for the same period for noradrenaline. In both the cases, tissues were then transferred to $10 \%$ neutral formalin for another $24 \mathrm{hr}$. After fixation, they were washed thoroughly in distilled water, and subjected to the routine procedures for paraffin sectioning. $15 \mu$ thick cross sections were deparaffinized in xylol and mounted in canada balsam.

For measuring the total catecholamine-containing as well as noradrenalinecontaining areas in the central sections of adrenal, the method as described by Roy et al. (1968) was followed. Camera lucida drawings of the total adrenomedullary zone and iodate-positive zone were made from the central sections on squared (mm) graph paper. The area traced on paper was measured by counting the squares on the graph paper they covered. The magnification was determined by drawing the $\mathrm{mm}$ scale of stage micrometer on the graph paper. The area traced on the graph paper was divided by actual magnification for determining the actual area in $\mu^{2}$.

\section{Observations}

Control lizards: Ghosh et al. (1973) have described in a previous communication the histology and relative distribution of cortical and medullary cells in the adrenal of Calotes. Tissue sections, stained with haematoxylin or eosin (Fig. 1) or treated with chromate-dichromate (Fig. 2) or iodate solution (Fig. 3) show that the medullary cells form a peripheral capsule around the centrally disposed cortical cells. This capsule is thicker at the dorsal side and sends cellular strands inside the cortical tissue.

Following the treatment with chromate-dichromate solution, the chromaffin cells take up yellow-brown colouration in various intensities. The overall intensity of the reaction appears to be more or less similar in the controls sacrificed at different experimental periods (Table 1). The iodate reaction reveals the iodate-positive cells in yellowish-brown colour occupying almost the entire spread of the medullary capsule and its strand. Individual variations with regard to the staining intensity 
in the control lizards at any of the experimental periods are not remarkably demonstrated. Measurements of the total adrenomedullary zone as well as iodatepositive zone are given in Table 2 .

The ascorbic acid (AA) in the cortical zone is localized in granular forms (Fig. 4). Individual variations in the AA concentrations are clearly observed at various experimental periods (Table 1).

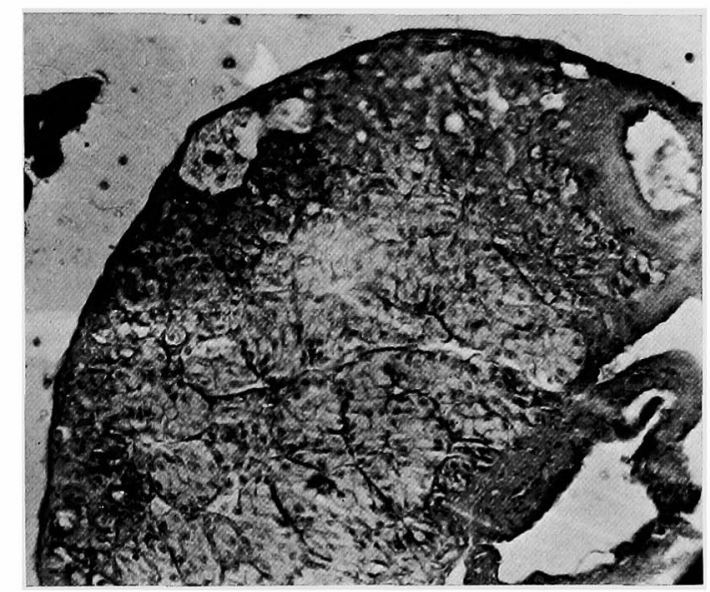

Fig. 1. C.S. of adrenal of control Calotes (at $24 \mathrm{hr}$ ) showing deeply stained peripheral medually zone and lightly stained central cortical zone. H and E. $\times 60$.

Table 1. Showing visual estimations of the concentrations of total catecholamines and noradrenaline in the adrenal medulla, and of ascorbic acid in the adrenal cortex of control and reserpine-treated Calotes at various experimental periods

\begin{tabular}{|c|c|c|c|c|c|c|}
\hline \multirow{2}{*}{ Hour } & \multicolumn{2}{|c|}{ Total catecholamine in medulla } & \multicolumn{2}{|c|}{ Noradrenaline in medulla } & \multicolumn{2}{|c|}{ Ascorbic acid in cortex } \\
\hline & Control & Treated & Control & Treated & Control & Treated \\
\hline 4 & $+++(3)$ & $++(3)$ & $+++(3)$ & $\begin{array}{c}++(2) \\
+(1)\end{array}$ & $\begin{array}{r}+++(2) \\
++(1)\end{array}$ & $\begin{array}{r}++(1) \\
+(2)\end{array}$ \\
\hline 24 & $+++(3)$ & $++(3)$ & $+++(3)$ & $++(4)$ & $\begin{array}{r}+++(1) \\
++(2)\end{array}$ & $\begin{array}{l}+(2) \\
\pm(1)\end{array}$ \\
\hline 72 & $+++(3)$ & $++(3)$ & $+++(3)$ & $++(3)$ & $\begin{array}{r}+++(1) \\
++(2)\end{array}$ & $\begin{array}{r}+++(2) \\
++(1)\end{array}$ \\
\hline 120 & $+++(3)$ & $++(4)$ & $+++(3)$ & $+++(4)$ & $\begin{array}{r}++\perp(2) \\
++(2)\end{array}$ & $\begin{array}{r}+++(1) \\
++(2)\end{array}$ \\
\hline
\end{tabular}

Figures in parentheses indicate number of animals whose adrenals were studied. ' +++ ', ' ++ ', ' + ' and ' \pm ' indicate the concentrations in descending order.

Treated lizards: Visual estimations of the concentrations of adrenomedullary catecholamines are shown in Table 1. The concentrations of the catecholamines in general, as shown by chromate-dichromate technique, and of the noradrenaline in particular, as shown by iodate technique, are depleted along with significant reduction in the chromate-dichromate-positive (total catecholamine-containing) 
area as well as iodate-positive (noradrenaline-containing) area at 4 and $24 \mathrm{hr}$ following injection with reserpine (Figs. 5 and 6; Table 2). At subsequent experimental periods (72 and $120 \mathrm{hr}$ ) after injection, such concentrations or areas, however, do not notably differ from those of the corresponding controls, Karyometric data
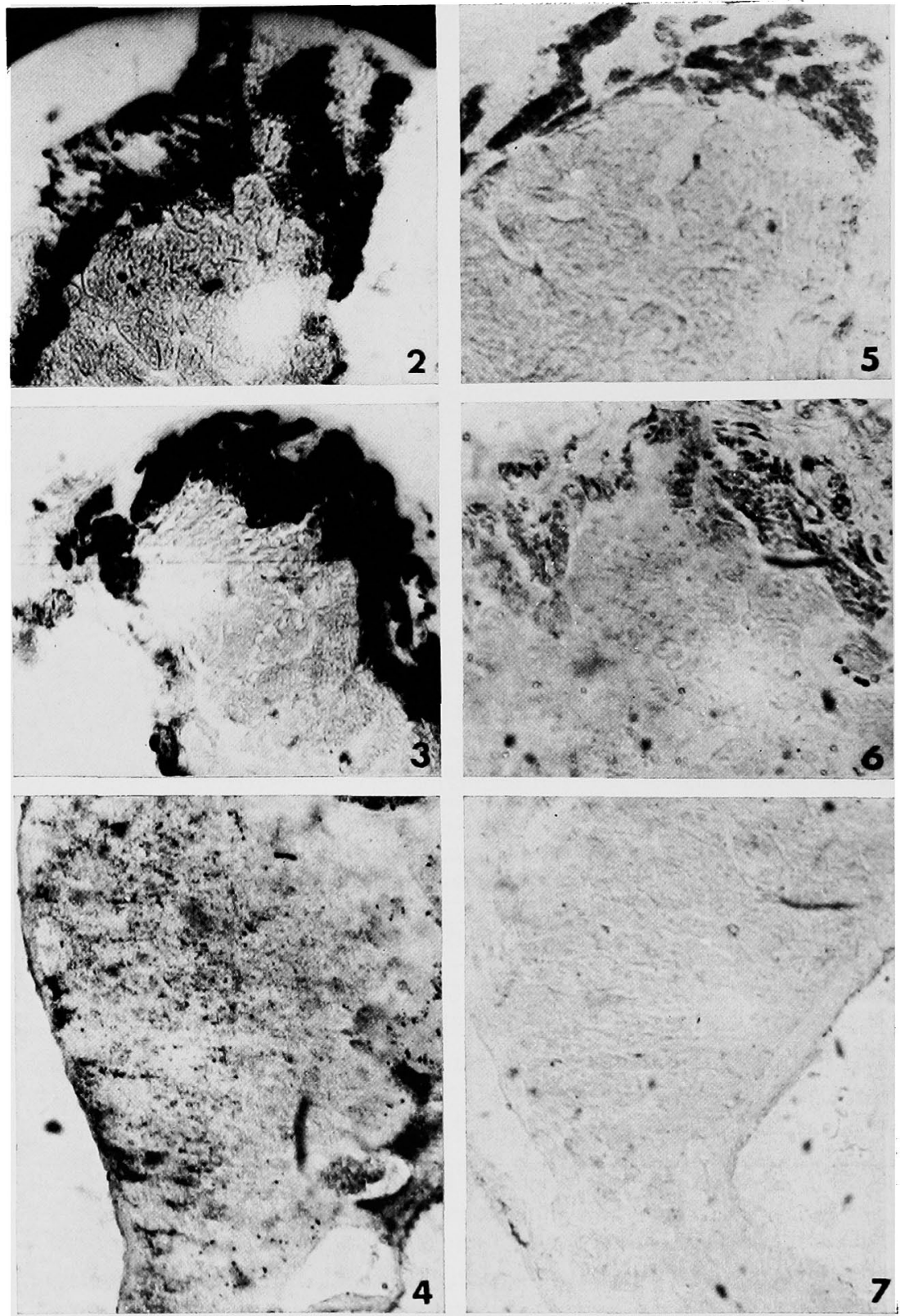

Figs. 2-4. C.S. of adrenal showing concentrations of catecholamines. 2, noradrenaline. 3, ascorbic acid. 4, in control Calotes at $24 \mathrm{hr}$ stage. $\times 100$.

Figs. 5-7. C.S. of adrenal showing concentrations of catecholamines. 5, noradrenaline. 6, ascorbic acid. 7, in treated Calotes at $24 \mathrm{hr}$ stage. $\times 100$. 
(Table 2), on the other hand, reveals no significant increase in the average nuclear volume in the treated lizards at any of the experimental periods.

The AA concentrations in the adrenocortical cells of the treated lizards show considerable individual variations as noted in the controls also. However, this
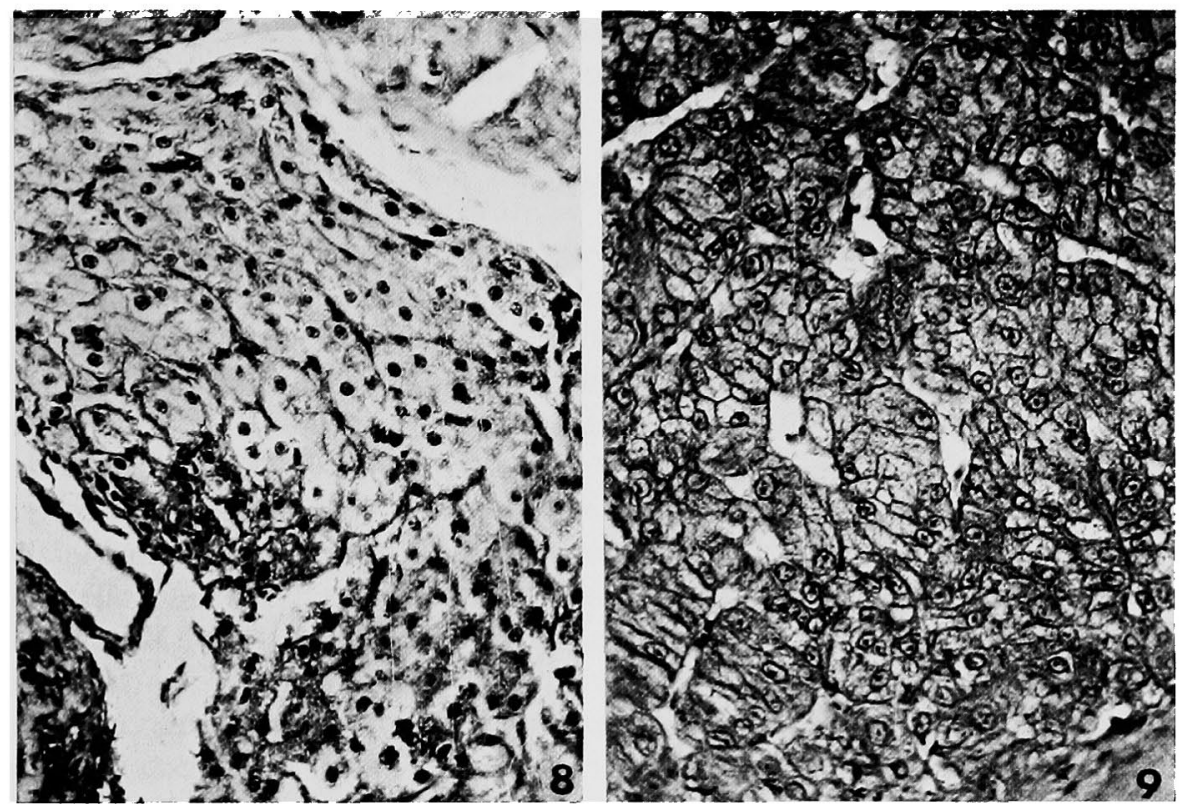

Figs. 8-9. Portion of C.S. of adrenal of control. 8, and 9, treated Calotes at $24 \mathrm{hr}$ stage. Note enlarged nuclei in the cortex in Fig. 9 where the deeply stained upper region represents the medulla.

$\mathrm{H}$ and $\mathrm{E} . \times 200$.

Table 2. Showing measurements of chromate-dichromate-positive (A) and iodate-positive (B) areas $\left(\mu^{2}\right)$ in medulla and average nuclear volumes $\left(\mu^{3}\right)$ of the medullary and cortical cells in the adrenals of control and reserpine-treated Calotes at various experimental periods

\begin{tabular}{|c|c|c|c|c|c|c|c|c|}
\hline \multirow{3}{*}{ Hour } & \multicolumn{6}{|c|}{ Medulla } & \multirow{2}{*}{\multicolumn{2}{|c|}{$\begin{array}{c}\text { Cortex } \\
\text { Nuclear volume }\end{array}$}} \\
\hline & \multicolumn{2}{|c|}{ A } & \multicolumn{2}{|c|}{ B } & \multicolumn{2}{|c|}{ Nuclear volume } & & \\
\hline & Control & Treated & Control & Treated & Control & Treated & Control & Treated \\
\hline 4 & $\begin{array}{c}49.53 \\
\pm \\
2.69\end{array}$ & $\begin{array}{c}27.46^{\mathrm{a}} \\
\pm \\
3.51\end{array}$ & $\begin{array}{l}45.56 \\
\pm \\
0.84\end{array}$ & $\begin{array}{c}10.78^{\mathrm{b}} \\
\pm \\
1.71\end{array}$ & $\begin{array}{c}310.68 \\
\pm \\
46.27\end{array}$ & $\begin{array}{c}253.35 \\
\pm \\
14.51\end{array}$ & $\begin{array}{c}287.14 \\
\pm \\
28.29\end{array}$ & $\begin{array}{c}321.66 \\
\pm \\
11.12\end{array}$ \\
\hline 24 & $\begin{array}{c}49.73 \\
\pm \\
1.23\end{array}$ & $\begin{array}{c}28.75^{\mathrm{a}} \\
\pm \\
4.28\end{array}$ & $\begin{array}{l}44.70 \\
\pm \\
3.00\end{array}$ & $\begin{array}{c}18.37^{\mathrm{a}} \\
\pm \\
1.59\end{array}$ & $\begin{array}{c}324.55 \\
\pm \\
32.04\end{array}$ & $\begin{array}{c}346.94 \\
\pm \\
40.10\end{array}$ & $\begin{array}{c}283.16 \\
\pm \\
14.61\end{array}$ & $\begin{array}{c}357.17^{\mathrm{c}} \\
\pm \\
21.48\end{array}$ \\
\hline 72 & $\begin{array}{c}53.56 \\
\pm \\
3.82\end{array}$ & $\begin{array}{l}44.23 \\
\pm \\
6.93\end{array}$ & $\begin{array}{l}41.95 \\
\pm \\
2.12\end{array}$ & $\begin{array}{c}32.32 \\
\pm \\
3.22\end{array}$ & $\begin{array}{c}264.86 \\
\pm \\
5.53\end{array}$ & $\begin{array}{c}326.53 \\
\pm \\
26.12\end{array}$ & $\begin{array}{c}262.97 \\
\pm \\
28.96\end{array}$ & $\begin{array}{c}299.37 \\
\pm \\
22.71\end{array}$ \\
\hline 120 & $\begin{array}{c}54.20 \\
\pm \\
3.13\end{array}$ & $\begin{array}{l}43.66 \\
\pm \\
2.63\end{array}$ & $\begin{array}{l}41.76 \\
\pm \\
3.36\end{array}$ & $\begin{array}{l}40.50 \\
\pm \\
1.47\end{array}$ & $\begin{array}{c}292.01 \\
\pm \\
46.12\end{array}$ & $\begin{array}{c}274.28 \\
\pm \\
18.70\end{array}$ & $\begin{array}{c}324.58 \\
\pm \\
39.37\end{array}$ & $\begin{array}{c}291.62 \\
\pm \\
36.05\end{array}$ \\
\hline
\end{tabular}

\pm SE. Average based on 3 individual values. $a=P<0.01, b=P<0.001, c=P<0.05$ 
concentration is distinctly below the corresponding control level in 2 individuals at $4 \mathrm{hr}$ and in 3 individuals at $24 \mathrm{hr}$ (Fig. 7) after the treatment (Table 1). No remarkable change in the AA concentration, in comparison with that in the corresponding controls, is noted at subsequent experimental periods. Karyometric study reveals that the average nuclear volume becomes significantly increased only at $24 \mathrm{hr}$ stage (Figs. 8 and 9) while at other experimental stages (4, 72 and $120 \mathrm{hr}$ ) no significant alteration in the average nuclear volume is noted (Table 2).

\section{Discussion}

Measurements of total catecholamine-containing cell area and noradrenalinecontaining cell area show that the latter is slightly lesser than the former. This indicates that possibly there are comparatively very few adrenaline-secreting cells in Calotes. The relative proportion of noradenaline-secreting cells is very high. Such conclusion, however, is drawn on the basis of histochemical findings only. Pending biochemical studies it is difficult to point out with enough degree of certainty whether adrenaline-secreting cells are present in very poor number or are absent totally. Within the limits of this investigation, however, it may be pointed out that noradrenaline is the predominant adrenomedullary hormone while adrenaline, if produced, is done so in very little quantity in comparison with the elaboration of noradrenaline.

Reserpine-induced greater or preferential depletions of any one adrenomedullary hormone have been reported in other vertebrate groups. For example, reserpine causes a preferential depletion of noradrenaline in rats (Camanni et al. 1958, Eränkö and Hopsu 1958) and pigeon (Ghosh and Ghosh 1963) and of adrenaline in rabbit (Viveros et al. 1969). Recently, Ghosh and Datta (1969) have observed that reserpine treatment for shorter period leads to a greater loss of noradrenaline in fowl and of adrenaline in crow while prolonged treatment indicates greater depletion of adrenaline in fowl and a total depletion of both the catecholamines in crow. The histological study of Olivereau (1963) on the adrenal of the eel Anguilla anguilla shows that reserpine-induced changes in the chromaffin cells are identical to that in higher vertebrates while the histochemical observations of Banerji (1970) on the fish Trichogaster trichopterus reveal that reserpine brings a definite depletion of adrenaline - the only catechol hormone histochemically detected in the chromaffin cells of the head kidney grandular parenchyma of this fish. In Calotes reserpineinduced depletion of noradrenaline at 4,24 and $72 \mathrm{hr}$ is evident from visual estimation of total catecholamines and noradrenaline concentrations as well as measurement of the chromate-dischromate-positive and iodate-positive cell areas. Within the limits of this investigation it is difficult to assert the presence of adrenalinesecreting cells in the adrenal medulla of Calotes. If these cells are present, the effect of reserpine on adrenaline is difficult to assess by the methods followed in the present investigation.

Karyometric study does not indicate any sign of activation (synthesis of hormone) of the medullary cells. Considering the hormone depletions as revealed from the visual estimations of the hormone concentrations, reduction in the cate- 
cholamine-containing areas and insignificant alteration in the average nuclear volume it may tentatively be suggested that the single high dose of reserpine induced depletion of the stored noradrenaline (and adrenaline?) but did not lead to significant activation of the adrenal cells.

Subjective estimations of ascorbic acid concentrations in the adrenal cortex show individual variations in both the control and treated lizards. Such individual variations among the members of a control or treated group, which may indicate individual differences in the physiological states of the individuals, have also been reported earlier among the control and X-irradiated lizards (Ghosh et al. 1972). However, in spite of the relative differences in the ascorbic acid concentrations among the control or treated lizards, a clear cut depletion of the ascorbic acid is apparent in most or all of the treated lizards at 4 and $24 \mathrm{hr}$ stages. At subsequent experimental stages such concentrations are similar to those in the corresponding controls. Depletion of the adrenal cholesterol or ascorbic acid is taken into account for assessing the degree of adrenocortical activity. The depletion of adrenocortical ascorbic acid in the reserpine-treated lizards at 4 and $24 \mathrm{hr}$ along with significant increase in their average nuclear volume at $24 \mathrm{hr}$ suggest that reserpine enhances adrenocortical secretion. Reserpine is reported to increase adrenocortical activity in rats (Maickel et al. 1961), and such activity is intense and long lasting (Eechaute et al. 1962). In Calotes, the applied dose $(0.8 \mathrm{mg} / 100 \mathrm{gm})$ of reserpine stimulates adrenocortical activity, and this hyperactivity persists at the initial experimental periods ( 4 and $24 \mathrm{hr}$ ) and subsequently attains the corresponding control level of activity.

In view of the fact that reserpine stimulates or inhibits adrenocorticotropic hormone under various conditions by acting on the nervous system in rat, guinea pig, dog, monkey and man (see Gold and Ganong 1967), it may be tempting to presume that the adrenocortical activation in Calotes is effected by stimulation of the corticotropic cells. However, as in many reptiles (see Saint Girons 1967) in Calotes too the ACTH cells are yet to be identified (Pahari and Banerjee, unpublished) and as such it is not possible to comment at the moment on this aspect in Calotes.

\section{Summary}

1. Cytomorphic and cytochemical studies were made on the adrenal cortex and medulla in the garden lizard, Calotes versicolor at 4, 24, 72 and $120 \mathrm{hr}$ stages following a single intramuscular injection of reserpine $(0.8 \mathrm{mg} / 100 \mathrm{~g}$ body wt.).

2. The concentration of the total catecholamines in general as well as noradrenaline in particular, and the total catecholamine-containing as well as noradrenaline-containing areas became reduced at 4 and $24 \mathrm{hr}$ stages, but remained similar to those in the corresponding controls at 72 and $120 \mathrm{hr}$ stages. Significant alteration in the average nuclear volume did not occur at any of the selected experimental periods. These findings indicated that reserpine induced initial depletion of the stored noradrenaline (and adrenaline?) but did not lead to any remarkable activation of the adrenomedullary cells.

3. The ascorbic acid concentrations in the adrenocortical cells in most or all 
of the experimented lizards decreased at 4 and $24 \mathrm{hr}$ stages but remained along the control level of concentrations at subsequent periods (72 and $120 \mathrm{hr}$ ). The average nuclear volume of these cells increased significantly at $24 \mathrm{hr}$ stage only. These findings indicated that reserpine stimulated adrenocortical activity that persisted at the initial experimental stages ( 4 and $24 \mathrm{hr}$ ) and subsequently attained the control level of activity.

\section{References}

Banerji, T. K. 1970. Alteration in the adrenomedullary hormones in a teleostean fish following reserpine treatment. Proc. Zool. Soc., Calcutta 23: 73-81.

Burger, M. 1957. Verändrungren der Adrenaline--und Noradrenalinkonzentrationen im menschlichen Blutplasma unter Reserpin. Arch. Exptl. Pathol. Pharmakol. 230: 489-498.

Camanni, F., Losana, O. and Molinatti, G. H. 1958. Selective depletion of noradrenaline in the adrenal medulla of the rat after administration of reserpine. Experientia 14: 199-201.

Carlsson, A. and Hillarp, N. A. 1956. Release of adrenaline from the adrenal medulla of rabbits produced by reserpine. Kgl. Fysiograf. Sallskap. Lund. 26: 90-91.

Eechaute, W., Lacroix, E. and Leusen, I. 1962. Effect inhibiteur de la tetrabenazine sur l'influence corticosurrenalienne de la reserpine. Experientia 18: 233-234.

Eränkö, O. and Hopsu, V. 1958. Effect of reserpine on the histochemistry and content of adrenaline and noradrenaline in the adrenal medulla of the rat and mouse. Endocrinology 62: 15-23.

Ghosh, A. and Datta, B. 1969. Effect of reserpine on the release of adrenomedullary catecholamines and their role in glycemic and pressor responses in two avian species. Gen. Comp. Endocrinol. Suppl. 2: 354-357.

Ghosh, (Miss) Amiya, Maity, L. K. and Banerjee, S. K. 1973. Effect of whole-body X-irradiation on the adrenal gland of the lizard, Calotes versicolor: a cytochemical study. Ind. Jour. Exptl. Biol. 11: 79-82.

Ghosh, I. and Ghosh, A. 1963. The effect of reserpine on adrenal medulla of the pigeon-a cytochemical investigation. Cytologia 28: 146-153.

Gold, E. M. and Ganong, W. F. 1967. Effects of drugs on neuroendocrine processes. In: Neuroendocrinology. Vol. II, pp. 377-437. Eds. Martini, L. and Ganong, W. F. Academic Press, N. Y.

Hertting, G., Axelrod, J. and Whitby, L. G. 1961. Effect of drugs on the uptake and metabolism of $\mathrm{H}^{3}$-norepinephrine. J. Pharmacol. Exptl. Therap. 134: 146-153.

Hillarp, N. A. and Hökfelt, B. 1955. Histochemical demonstration of noradrenaline and adrenaline in the adrenal medulla. J. Histochem. Cytochem. $3: 1-5$.

Maickel, R. P., Westermann, E. O. and Brodie, B. B. 1961. Effects of reserpine and cold exposure on pituitary adrenocortical function in rats. J. Pharmacol. Exptl. Therap. 134: 167-175.

Olivereau, M. 1963. Action de la reserpine sur l'hypophyse, l'interrenal et les cellules chromaffines de l'anguille, Anguilla anguilla L. C. r. Seanc. Soc. Biol. 7: 1357-1360.

Ray, A. K., Mukherji, M. and Ghosh, J. J. 1968. Adrenal catecholamines and related changes during different phases of morphine administration-A histochemical study. Jour. Neurochem. 15: 875-881.

Saint Girons, H. 1967. Morphologie comparée de l'hypophyse chez les Squamata: données complementaires et apport à la phylogénie des Réptiles. Ann. Sci. Nat. Zool. 12(9): 229-308.

Srebro, Z. 1970. Morphofunctional study of hypothalamic neurosecretion V. The effect of light and temperature in Rana temporaria. Folia biol. (Kraków) 18: 237-244.

Viveros, O. M., Arqueros, L. and Krishner, N. 1969. Mechanism of secretion from the adrenal medulla $\mathrm{V}$. Retention of storage vesicle membranes following release of adrenaline. Mol. Pharmacol. 5: 342-349.

Zarrow, M. X., Yochim, J. M. and McCarthy, J. L. 1964. Experimental Endocrinology. p. 208. Academic Press. N. Y. 